\title{
Generation Z and technologies on museums - Its influence on perceptions about Quality, Arousal and E-WOM Intentions
}

A geração $Z$ e o uso de tecnologias em museus - Sua influência na percepção de qualidade, na excitação gerada e na intenção de recomendar online

\author{
Wilian R. Feitosa, (wrfeitosa@hotmail.com) Instituto Federal de São Paulo, Brasil \\ Robson Barbosa (prof.robson@ifsp.edu.br) Instituto Federal de São Paulo, Brasil
}

\section{RESUMO}

Os museus são instituições educacionais que nutrem e mantêm o patrimônio cultural da humanidade, desempenhando papéis vitais no desenvolvimento econômico, atraindo turistas locais e estrangeiros. No entanto, o futuro dos museus como destino pode ser significativamente afetado por novas tecnologias. Isso é particularmente relevante, considerando a educação e as expectativas da Geração Z. De fato, sua satisfação pode resultar em recomendações da E-WOM, aumentando a visitação. Os museus podem aumentar a percepção da qualidade, a excitação e a intenção de recomendação, aumentando o uso da TI, o que pode mudar a experiência do visitante. Testamos o relacionamento entre as intenções de recomendar, a excitação e a percepção de qualidade com a tecnologia usada. Os resultados mostram uma forte correlação entre percepções de qualidade e excitação $(0,68)$ e entre excitação e intenção de recomendação $(0,87)$ quando um nível mais alto de uso de TI foi apresentado. Apesar dos níveis de tecnologia permitirem uma carga emocional mais alta e maiores intenções de recomendação do e-WOM, os problemas operacionais continuam sendo importantes. Em vez de apenas aumentar os gastos em tecnologia, é necessário se concentrar em treinamento e organização interna. Além disso, as tecnologias podem ajudar não apenas a tornar o conteúdo mais atraente, mas também mais compreensível.

Palavras-chave: tecnologias para museus, satisfação, experiência, WOM. 


\section{ABSTRACT}

Museums are educational institutions that nurture and maintain cultural heritage of humanity, playing vital roles in economic development by attracting local and foreign tourists. However, the future of museums as destination can be significantly affected by new technologies. That is particularly relevant, considering Generation Z's education and expectations. In fact, their satisfaction can result in E-WOM recommendations, increasing visitation. Museums can increase quality perception, excitation, and recommendation intention by increasing IT usage, what can change visitor experience. We test the relationship among E-WOM intentions and arousal based on technology. Results show a strong correlation between quality perceptions and arousal $(0,68)$ and between arousal and E-WOM intentions $(0,87)$ when a higher level of IT usage was presented. Despite technology levels allowing a higher emotional charge and greater e-WOM recommendation intentions, operational issues are already important. Instead of just increasing spending on technology, it is needed to focus on training and internal organization. Also, technologies can help not only to make content more attractive, but more understandable.

Keywords: IT for museums, satisfaction, experience, WOM

\section{INTRODUCTION}

Museums have a huge cultural significance as part of the cultural heritage of a community, city, or country. They are safekeepers of art and legacy, as much as educational institutions are. Also, they play vital roles in economic development by attracting both local and foreign tourists. Some of them are considered "super-museums", worldwide famous, admired and capable to attract touristic demand by itself (Frey, 1998). However, the future of museums as a destination can be significantly affected by new technologies. Recently, the operation of museums has already changed. Information technology has been part of changes to scenarios and has presented a challenge to curatorship. Such technology has included portable devices, personal guiders, panels, animations, virtual reality, films, and projections on a stage, in order to enable visitors to have deeper experiences and in order to attract 
new kind of visitors. All these devices can contribute towards creating a better visitor experience, making even trivial attractions highly exciting. It is particularly relevant, considering Generation Z's education and expectations. This generation has been using a lot of technologies since their childhood. Museums, in order to follow this, and to maintain their attractiveness, need to consider this generation when formulating strategies.

Moreover, their satisfaction can result in comments and recommendation on social networks, increasing the number of visitors from this demographic. But how can technologies influence Gen $Z$ satisfaction? And how much satisfaction can increase Gen Z engagement on social networks, leading them to recommend museums and to persuade others?

This study aims to understand these technologies-analyzing their impact on Generation Z's satisfaction with museums' services; on their experiences and its influence on perceptions of quality and intentions to share e-WOM recommendations; and technologies' importance to museums' strategies. It will describe these technologies, discuss them from a strategic point of view, and illustrate this in a survey with Gen Z students.

This study was performed in the city of São Paulo. São Paulo's touristic demand comes to the city for business, shopping, cultural life and events. There are more than 100 museums in this city, and some of them are listed in worldwide rankings of most visited or most admired museums. Museums are attractions to keep visitors on any city, increasing their spending, and it is common people visiting São Paulo staying in the city some extra time after business to come to them. Moreover, many groups of students, organized by their schools, from cities nearby São Paulo, come to visit them. So, Gen Z students, in groups or alone, are important to São Paulo's museums, and, certainly, to any museum of the world, to increase present and future visitation. In one hand, they contribute helping to attract more visitors, by recommending to friends, or publishing content on social media, or making 
good evaluations on specialized sites, such as Trip Advisor. Another hand, it is strategic, to build relationships. Brida, Meleddu and Pulina (2012) have studied which visitors are more likely to come back, revisiting. They argue that revisitors used to be part of the community close to the museum, and demographic factors are correlated to revisiting intention.

\section{THEORETICAL FRAMEWORK}

Marketing of any destination is influenced by characteristics of their offer, such as attractions, prominence and positioning. Museums, besides acting as safekeepers of legacy or educational institutions, can help economic development by attracting and keeping on the city both local and foreign tourists. They can help on destination marketing, especially those of them considered "super-museums", which are worldwide famous, admired and capable to attract touristic demand by themselves (FREY, 1998). Some of them are recommended on travel guides, and other are intrinsic part of a destination positioning, once there is a cult around them, for instance, the relation between cities like Rome and Paris and its museums, such as Vatican and Louvre. Therefore, museums can be strategic to destination marketing once they can change the way this place is seen, beyond attract visitors and resources.

Several regions around the world could change their city or country brand positioning by investing in museums - for instance, Singapore (Ooi, 2003), Florence, Italy (Lazzeretti \& Capone, 2015) or Bilbao (Plaza, 2000). Moreover, their capacity to promote events, attracting people and attention, to engage people in a chain of values and to start new productive local arrangements, is strategic to public power and all stakeholders in the region. Museums can also attract sustainable development. 
Museums represent a very special form of nonprofit organizations in the service sector. In some countries, all resources to their finance sustainability are provided by the private sector, such as by selling tickets, donations, or sponsorships. By contrast, some countries adopt a model in which there is direct involvement of public administration, and public resources are invested in culture and, by extension, on museums. Also, there is a third way-one in which museums are a public-private partnership, and in which resources can come from either of these two sides.

Nevertheless, museums' management needs to be prepared for the future, for the long run, analyzing how to lead their organizations both to win the competition and to add value for their stakeholders.

Among a museum's relevant stakeholders, it is possible to cite visitors, sponsors, donators, local government, employees, managers, artists, suppliers, and the community in general. Each of them has proper and, in some cases, conflicting interests. For instance, while visitors can want longer opening hours or free tickets, employees or managers could demand the opposite. Museums' strategy demands the correct balance of these interests in the long run.

In order to discuss their strategies, museums, as a service, need to know how value is created for their stakeholders. What are the functional and emotional benefits? What are the customers' costs? Value is measured, intuitively, by the relation of these benefits and sacrifices (Kotler, Kotler \& Kotler, 2008).

Value is the most important concept in a service strategy. Likewise, it is no different for museums. Strategy in the provision of services needs to consider visible and invisible operational aspects, as well as non-operational aspects. Both of them can increase or undermine service value.

Another key concept in services strategy is the consumer experience (which is what the consumers have experimented with during the service execution), 
as compared with their expectations. In other words, how satisfied is the consumer after the service is done? The main strategic objective of any museum is to provide visitors with the best experiences as compared to that provided by the competition (whether other museums or any other kind of entertainment or cultural experience).

Derbaix and Gombault (2016) explains that museums' experiences can be based on material dimension experiences, both visible (what is accessible to consumers; for instance, tables in a restaurant) and invisible (what is not visible to consumers; for instance, how fruits and vegetables are stocked in a restaurant); on operational aspects; or on immaterial dimensions (such as the atmosphere, aura, and reputation of the museum). Visitors' imaginations and their immersion in a narrative allow them to be transported to a territory where the museum is considered as being authentic.

Therefore, it is important to think about tangible and intangible aspects in a museum, in order to project a service which allows for alignment to high standards of tangible aspects of a service with immaterial and intangible aspects.

The first step in this project task is the concept of the museum, its mission, and the reason for its existence. However, defining this concept, in turn, necessitates consideration of how the market is: its segmentation, and how attractive each segment is. What kind of visitors to, donators to, or sponsors of this concept of museum is best? This task, in turn, makes it necessary to look to the market to analyze how the competitors are performing and to answer question like these: What are the competitors doing? Is there some service or segment that is forgotten? How can the museum be different from them, and how can it be innovative so as to make the competition irrelevant? Segmentation includes identify differences among consumers in demographics, geography, psychographics, and behavioral patterns (Kotler et al., 2008). 
The next step is to decide how to adapt the operation, in order to follow that idea. This is positioning. Kotler et al. (2008) argue that it is possible for a museum to be positioned to interest a certain kind of user, in terms of its attributes or its benefits. For instance, a Natural History museum is positioned in terms of its attributes, but its operation can be positioned on students; whilst a Modern Art museum has other attributes, so maybe its focus is on another kind of user, perhaps art merchants and artists.

To make execution work, all actions (communication included) need to be defined and adjusted in order to follow strategy. Moreover, Lovelock and Wirtz (2011) state that service delivery strategies need to align operational and promotional efforts to succeed.

Kamal and Pramatic (2015) argues that, in museums, several factors can boost this: If cultural and anthropological factors are valuable in helping have an influence on visitor decision, promotional efforts are as important as learning and aesthetic factors are. Among these promotional efforts, social media can act as a direct avenue of communication between museums and visitors, and amongst visitors (Russo, Watkins, Kelly \& Chan, 2007). Therefore, social media is an important part of museum marketing, helping to keep visitors informed and satisfied - to ensure a revisit, a recommendation, and the promotion of its intangible heritage (Richani, 2016).

Researchers have studied what increases the likelihood of e-WOM (electronic word-of-mouth) recommendations; for example, factors studied include both emotional involvement and excitement about visitation experience. Berger and Milkman (2012) and Botha and Reyneke (2013) argue that people used both to engage on e-WOM and share content when they are emotionally involved.

Museums' marketing needs e-WOM recommendations to reach visitors. Hausmann (2012) shows an analytical framework to increase the likelihood to get visitors recommendations. Some models have explored relations among 
WOM recommendation intentions and satisfaction with museums - for example, Burton, Louviere and Young (2009) study, that analyzes visit repetition choice based on WOM, or Carrasco-Santos and Padilla-Meléndez's (2016) study, that analyses this relation in the case of a museum on Spain. But none of them focused on technologies on museums, nor did they consider Generation Z.

\section{MUSEUMS, AROUSAL, AND PERCEPTION OF QUALITY}

By its nature, it is not possible to indicate the quality of a service before delivery (Lovelock \& Wirtz, 2011). To evaluate customers' perception of quality, it is needed asking directly to costumer. One way to do this is by measuring customers' expectations before service delivery, comparatively, to measuring the perception of service performed, identifying if there is a disconfirmation, that is, how much a user was frustrated with the provision of services, or a confirmation, when the service follows the standards expected (Lovelock \& Wirtz, 2011).

Parasuraman, Zeithaml, and Berry (1988) proposed the SERVQUAL scale. It measures the quality of a service by comparing expected and perceived service in 22 items, divided into different constructs: tangibility, reliability, responsiveness, communication, understanding of customer needs, and ease of access.

Frochot and Hughes (2000) adapted the SERVQUAL scale to museums' operation and measured museum quality through the HISTOQUAL scale. Kim, Ritchie, and McCormick (2012) and Burton et al. (2009) have used it successfully. It measures quality comparing what consumers expected and their perception about real service in 21 items divided into 5 constructs: tangibility, empathy, communication, presentation, and ease of access. 
Museum managers around the world have realized that entertainment, leisure, and education are legitimate parts of their repertoire (Gosling, Coelho \& Resende, 2014). In a context where competition of leisure alternatives and tourist attractions is high, museums should focus intensely on visitor satisfaction, which can contribute to the return of visitors and to word of mouth recommendations.

Entertainment can lead to emotional intensity and better experiences (Hackley \& Tiwsakul, 2006). If it were positive and intense emotions, the experience will be memorable and, probably, the visitor will express approval and recommend to others, included youngsters (Waiguny, Nelson \& Terlutter, 2012). Arousal is a measure of how active and intense an emotion is (Berger, 2011). Berger (2011) states that more arousal leads to more social information transmission.

This allows the authors to make a hypothesis:

$\mathrm{H} 1$ : Confirmation of the quality of museums' service is related to an arousal felt about the service.

\section{TECHNOLOGIES SUPPORTING MUSEUMS SERVICES}

Technologies can support museums' operations in different ways. It is possible to enhance experiences and turn the visitor in an immersive and emotional service. It can help inside the museums, by providing information, giving to the visitors the opportunity of participate, giving their opinions on social media, on blogs. Animated panels help to visitor know the work and relation among works. Handheld and audio guides give to visitor more information, completing the experience. Virtual reality, interactive, and electronic games surprise visitors, especially the young ones. Video and digital art can be surprising as well. McCarthy and Ciolfi (2008) argues that visitors' experience is 
related to the level of information provided, and all these technologies can contribute on that way.

Moreover, Swiss and Hanna (2004) and Fraga (2017) show different ways in how art can incorporate technology, exploring new possibilities, thresholds and languages, for example, works using games language, incorporing videos or, even, artificial intelligence. Artists have tried to incorporated these technologies as well, and museums' curators can consider that on creation of an exhibition.

On the internet, museums can turn information available to community. Visitors can share artworks, and prospects can see the schedule and opening hours (Vrana et al., 2019). Curators can see the catalog, and possible donators can see financial statements (Camarero, Garrido \& San Jose, 2016). Some museums are organizing online exhibitions (Srinavasan, Boast, Becvar \& Furner, 2009). Others, just exist online. They are the virtual museums (Christal, Roy \& Cherian, 2004; Christensen, 2017; Dossin \& Riphagen, 2017). See all these options in Table 1.

This allows the authors to make a hypothesis:

$\mathrm{H} 2$ : High level of technologies in museums makes Generation $\mathrm{Z}$ have greater arousal, e-WOM recommendations, and perception of quality.

Table 1. Some technologies enhancing visitor experience

\begin{tabular}{|c|c|c|c|c|}
\hline Place & Technology & Explanation & Authors & \\
\hline \multirow[t]{2}{*}{$\begin{array}{l}\text { Inside } \\
\text { museums }\end{array}$} & $\begin{array}{l}\text { Virtual } \\
\text { reality and } \\
\text { augmented } \\
\text { reality }\end{array}$ & $\begin{array}{l}\text { Virtual reality, or augmented reality, allows user see more than the } \\
\text { reality using glasses that amplify the vision, mixing GPS information, } \\
\text { and adding some images over the real images. Games, artwork, and } \\
\text { even movie makers can simulate art in reality using this technology. } \\
\text { It is possible, for example, to make pictures animated, to simulate } \\
\text { virtual tours, and to add information about works. }\end{array}$ & Gomide (2017) & \\
\hline & Panels & $\begin{array}{l}\text { Panels and Interaction design can improve experience for visitors } \\
\text { and staff, providing information that can be useful in } \\
\text { interpretations of museum experience: relational, open sense } \\
\text { making, narrative, and spatio-temporal. }\end{array}$ & $\begin{array}{l}\text { McCarthy and } \\
\text { (2008) }\end{array}$ & \\
\hline
\end{tabular}




\begin{tabular}{|c|c|c|c|}
\hline & $\begin{array}{l}\text { Handheld } \\
\text { guides }\end{array}$ & $\begin{array}{l}\text { Handheld guides, PDAs, and audio guides can enhance experience. } \\
\text { It is possible to increase involvement with creativity, for instance, } \\
\text { with storytelling toy animals or some other character. }\end{array}$ & Tallon and Walker (2008) \\
\hline & $\begin{array}{l}\text { Open access } \\
\text { to social } \\
\text { media }\end{array}$ & $\begin{array}{l}\text { Provide access to social media to visitors for improve their learning, } \\
\text { mainly among youngsters. }\end{array}$ & $\begin{array}{l}\text { Charitonos, Blake, Scanlon, } \\
\text { and Jones (2012); Vavoula, } \\
\text { Sharples, Rudman, Meek, } \\
\text { and Lonsdale (2009); Russo, } \\
\text { Watkins and Groundwater- } \\
\text { Smith (2009) }\end{array}$ \\
\hline & $\begin{array}{l}\text { Digital art; } \\
\text { video art }\end{array}$ & $\begin{array}{l}\text { Electronic art is experimental and goes beyond the boundaries of a } \\
\text { traditional museum. }\end{array}$ & Swiss and Hanna (2004) \\
\hline & $\begin{array}{l}\text { Cell phone } \\
\text { apps }\end{array}$ & $\begin{array}{l}\text { Cell phone apps can provide maps, audio guides, and further } \\
\text { artwork information. }\end{array}$ & Tallon and Walker (2008) \\
\hline & $\begin{array}{l}\text { Interactive } \\
\text { art and } \\
\text { games }\end{array}$ & $\begin{array}{l}\text { Works that allow participation and demand action of the visitors. } \\
\text { They can change the work by direct manipulation or, instead, by } \\
\text { means of a brain computer interface. }\end{array}$ & Fraga (2017) \\
\hline \multirow[t]{5}{*}{$\begin{array}{l}\text { On the } \\
\text { internet }\end{array}$} & $\begin{array}{l}\text { Blogs about } \\
\text { museums' } \\
\text { works }\end{array}$ & $\begin{array}{l}\text { Blogs about museums are a good way to make visitors be in a } \\
\text { participatory position, allowing dialogue and interaction. }\end{array}$ & $\begin{array}{l}\text { Pierroux, Krange and } \\
\text { Sem (2011) }\end{array}$ \\
\hline & $\begin{array}{l}\text { Digital } \\
\text { museum } \\
\text { catalog }\end{array}$ & $\begin{array}{l}\text { An online museum catalog that enables social tagging and blogging } \\
\text { activity around a set of cultural heritage objects. The example is } \\
\text { Blobgects, a platform held by a preeminent museum of } \\
\text { anthropology and archaeology. }\end{array}$ & $\begin{array}{l}\text { Srinavasan, Boast, } \\
\text { Becvar and Furner } \\
(2009)\end{array}$ \\
\hline & $\begin{array}{l}\text { Social } \\
\text { museums }\end{array}$ & $\begin{array}{l}\text { Museums need to be on social media and to use their accounts to } \\
\text { promote their exhibitions and to keep their relationships with } \\
\text { stakeholders (including visitors, press relations, donors, other } \\
\text { museums, and the artistic community) }\end{array}$ & $\begin{array}{l}\text { Geismar and Mohns } \\
\text { (2011); Claes and Deltell } \\
\text { (2014); Suzić, Karlíček } \\
\text { and Stř́teský (2016); } \\
\text { Vrana et al (2019) }\end{array}$ \\
\hline & $\begin{array}{l}\text { Website } \\
\text { providing all } \\
\text { information }\end{array}$ & $\begin{array}{l}\text { Museums' websites can provide information such as sustainability, } \\
\text { presence on social networks, podcasting, videocasting, catalog, } \\
\text { virtual tour, blog, e-mail contact, annual reports, history of the } \\
\text { museum, press room, catering, opening hours, and scheduling of } \\
\text { exhibitions, among others. }\end{array}$ & $\begin{array}{l}\text { Bonacchi (2017); } \\
\text { Camarero, Garrido and } \\
\text { San José (2016) }\end{array}$ \\
\hline & $\begin{array}{l}\text { Virtual } \\
\text { museums }\end{array}$ & $\begin{array}{l}\text { Virtual museums are online platforms for exhibiting artworks on the } \\
\text { internet - whether without a physical exhibition, or as part of a } \\
\text { copy strategy integrating online and offline content (Hybrid } \\
\text { publication). Some works are constantly in exhibition online, while } \\
\text { others are only exhibited offline. }\end{array}$ & $\begin{array}{l}\text { Christal, Roy and Cherian } \\
\text { (2004); Christensen } \\
\text { (2017); Dossin and } \\
\text { Riphagen (2017) }\end{array}$ \\
\hline
\end{tabular}

Source: authors

\section{Generation Z Characteristics - anecdotal evidence}

Generational cohorts are social concepts which state that all people born in a given period and a region, in which cultural similarities exist, will have similar characteristics, values, opinions, and attitudes as a function of their history of 
life and previous experiences (Ryder, 1965). Several sociologists have studied how these processes work since the XIX century, including August Comte, Karl Mannheim, Ortega y Gasset, Julian Marías, among others (Becker, 1991). They focused on questions such as how values are adopted among generations, tradition, conflicts among generations and their civil participation.

Strauss and Howe (1991) have proposed a way to understand how different generations have lived on USA history, based on historical facts. They believe that generations' succession is a cycle, and nowadays it is the millenium cycle, with three adults generations living: Boomers (born between 1940 and 1960), Thirteeners (born between 1960 and 1980) and Millennials (born between 1980 and 2000). Smith and Clurman (1997) have analyzed three generations, but only in terms of patterns of consumption. They considered different ranges to each generation, and the names have changed to Matures, Boomers and Xers. These two works could foresee how technology could be a factor to make differences among these generations. Levels of usage of internet and mobile phones have grown among all the generations, but it was expected that the generation after the Millennials (or Generation $\mathrm{Y}$ ) was born and, since then, has grew up among these technologies. Boomers are trying, Xers have learnt, Millennials created some of these technologies, and Generation $\mathrm{Z}$ is native digital, who was born among technologies. Generation $Z$ is a term created to designate people who were born between 1994 and 2005 in the United States. These people have had similar experiences, having used mobile phones and tablets since their childhood.

Perhaps this could be the most globalized generation in history. Arts, mass communication, and the internet are mixing cultures and are making all of them similar in several points.

Priporas, Stylos and Fotiadis (2017) shows that this generation, regarding retail, expects various new devices and electronic processes to be widely available, thus offering consumers more autonomy and faster transactions. In addition, 
they expect the technology to enable them to make more informed shopping decisions. For example, Turner (2015) remembers that no other prior generation has had an involvement with technology greater than that of Gen Z; for example, issues as cyberbullying, attachment to devices, high frequency use of social media, and continuous partial attention are common amongst them.

Jacobsen and Forsten (2011), in a study considering students in the first year on college, have discovered a negative relation between usage level of mobile phones and grades in the school, and many of students used electronic devices to multitask during the classes. In other hand, Mastrodicasa and Metellos (2013) argues that the level of usage of social media sites can be positive, considering an increase of social capital and allowance to students find partners to activities, or negative, decreasing their attention or engagement on classes, multitasking. Carrier et al (2009) corroborates on these findings - newer students, more frequently multitasking. Also, Lankin and Fink (2016) pointed to FoMo - fear of missing out, a kind of obsession to observe what people are doing on social networks and to publish what a person is doing, as a mental disease. Bolin and Westlund (2009), Chung et al (2010) and Helpster and Eynon (2010) argue that generation is just one of predictor to higher level of use of digital technologies, and some adults can be digital natives as well. Perceived usefulness is a predictor to higher levels of usage, and it does not change to age.

Regarding international similarities on this generation, Issa and Isaias (2016) have compared people from Australia and Portugal in the same age, from this generation. Among positive points of them, they list, for example, problem-solving skills, proactive study, information gathering, and awareness globally and locally; communication and collaboration with their peers and family were improved and enhanced. Alternatively, this study identifies new negative factors as being that physical contact and physical activities were 
prevented; thinking, concentrating, and memory skills were reduced; and that depression and isolation, and laziness, having increased.

Talking about Generation Z with regards to Romania, Runcan (2015) argues that many people of this generation have a profound relation with social media - a relationship he called "Facebookmania," an addiction to the use of Facebook: $10 \%$ of Generation $Z$ respondents answered by describing themselves as being addicted to social media.

\section{Gen $\mathrm{Z}$ and E-WOM Recommendations}

Generation Z has worldwide repercussions. People between 14 and 25 years tend to have a strong connection with social media, mobile phones, and games. Their use of social media includes recommendations of the use of products and services. These recommendations can occur online - whether by transmitting or retransmitting reviews or any shareable content such as text, photos, or videos - or offline, in a simple dialogue among family and friends (Feitosa \& Lourenço, 2018).

Among Generation Z individuals from Indonesia, Samodra and Mariani (2012) argue that it is needed that any content be useful and easy to manage. Among individuals from all ages and generations, arousal is also considered as being a predictor of e-WOM recommendations (Berger \& Milkman, 2012). This makes it important for museums to consider how to include Gen Z expectations of their service.

This allows the authors to make a hypothesis:

H3: High level of technologies in museums turns the relation between Generation Z's arousal and e-WOM recommendation intention stronger.

\section{CONCEPTUAL MODEL}




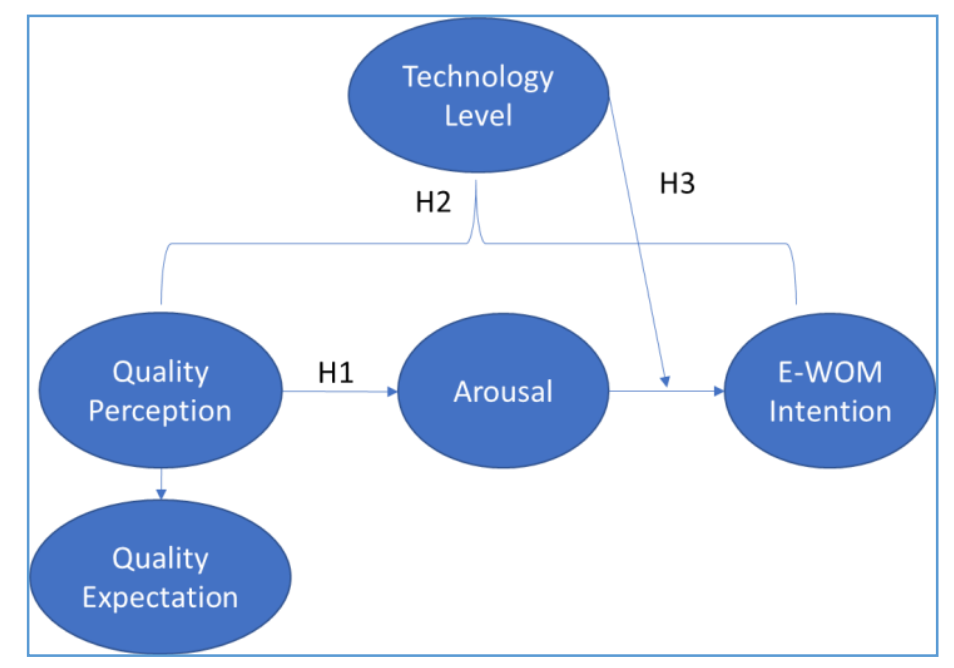

Figure 1: Conceptual Model

\section{METHODOLOGY}

São Paulo is one of biggest cities in the world, with a population exceeding 12 million people in 2016, and exceeding 20 million if nearby cities in the region are considered. Moreover, in the whole state of São Paulo, there are 45 million people. In the state of São Paulo, there are 517 museums, and in the city, 132 museums, but just 78 opened. In 2015, just the top 10 museums of the city have attracted above 3 million people. The first public museum in São Paulo, Museu da Imagem e do Som de São Paulo (MIS), has attracted 603,000 visitors in 2015. 98\% of São Paulo's museums offer guides, and 5\% of them offer audio guides (IBRAM, 2011).

This is an experimental study focused on museums' services. The experimental design is $2 \times 1$ (high and low technology). Nine museums were chosen, and the criteria were:

a) To be among the biggest of the city, in terms of number of visitors,

b) To optimize time expenditure and logistic costs,

c) To be recommended by São Paulo touristic authority and 
d) Attractiveness to target.

Participants were students of a technical high school, which could get extra credits. Different groups of students visited all the museums, and it was not allowed to visit a second museum to participate. It was allowed to invite a friend, whether it was available places on transportation.

Fifteen visits to museums happened between June 2015 and December 2016, with participants totaling 331. Excluding missing values and incomplete questionnaires, 298 valid questionnaires were gathered. Sample size was defined by the minimum number of respondents on each museum, considering data collection by convenience, and the exploratory purpose of this research.

Based on this, this study compares data collected from 298 Brazilian technical high school students who visited nine museums. Specifically, it compares data regarding three museums (which had a high-level use of technology) against six traditional museums (which had a low-level use of technology). It analyzes students' perception of quality-doing so based on Frochot's and Hugues' (2000) HISTOQUAL scale; perceived arousal; and WOM recommendation intentions (Kim et al. 2012, Bruyn \& Lilien 2008).

All museums were described in Table 3. Among nine museums, four museums are focus on abstract, modern, and contemporary art (Modern Art Museum, Contemporary museum, Federal, and Pinacoteca); two of them are focused on representative, sacred and folk art (Afro and Sacred Art); two of them are focused on historical and scientific purposes (soccer; catavento; and the Portuguese language).

Students filled in the Part A of the questionnaire, about expectations, on the school, before starting the travel. After the visit, they filled in Part B, about perceptions; Part C, about arousal and WOM recommendation intentions; and Part D, about personal information (demographics). 
All scales were reliability measured, with Cronbach's alpha above 0.8 : HISTOQUAL - Expectation was 0.93; HISTOQUAL - Perceptions, 0.90; Arousal scale, 0.88; and e-WOM recommendation intentions scale, 0.95.

The arousal scale was designed to measure how the content makes people feel emotionally touched, and to measure the level of emotional charge; doing so using 3 items. The WOM recommendation intention scale (7 items) was designed to measure if the respondent would recommend on social networks and talk about the museum with friends and family. See the complete scale on table 2 .

Table 2: Scales used

\begin{tabular}{cl}
\hline Scales & \multicolumn{1}{c}{ Itens } \\
\hline Arousal & 1. The museum impressed me \\
2. The museum touched me & \\
3. The museum made me feel like acting \\
4. I would comment on this museum in a virtual social network. \\
5. I would like this museum in a virtual social network \\
6. I would send photos and videos about this museum to my contacts in a \\
virtual social network \\
7. I would talk about this museum with my friends outside a virtual social \\
network \\
8. I will praise about this museum outside of a virtual social network \\
9. I will recommend this museum if someone asks me for opinion outside of a \\
virtual social network \\
10. I will encourage my friends and relatives to visit this museum \\
1. "In good museums" (for expectations) or "in this museum" (for perception), \\
employees are educated and want to help \\
and \\
2. "In good museums" (for expectations) or "in this museum" (for perception), \\
employees stay with visitors willingly \\
scale) \\
3. "In good museums" (for expectations) or "in this museum" (for perception), \\
stocking and concentration of people are tolerable \\
4. "In good museums" (for expectations) or "in this museum" (for perception), \\
the staff are knowledgeable \\
5. "In good museums" (for expectations) or "in this museum" (for perception), \\
there is no restriction on access and all are free to explore the museum \\
6. "In good museums" (for expectations) or "in this museum" (for perception), \\
the opening hours are adequate \\
7. "In good museums" (for expectations) or "in this museum" (for perception), \\
sufficient information is available \\
8."In good museums" (for expectations) or "in this museum" (for perception), \\
there is sufficient educational content of the exhibitions \\
9."In good museums" (for expectations) or "in this museum" (for perception), \\
there is attractive content of exhibitions \\
10. "In good museums" (for expectations) or "in this museum" (for \\
perception), the exhibits are well explained
\end{tabular}




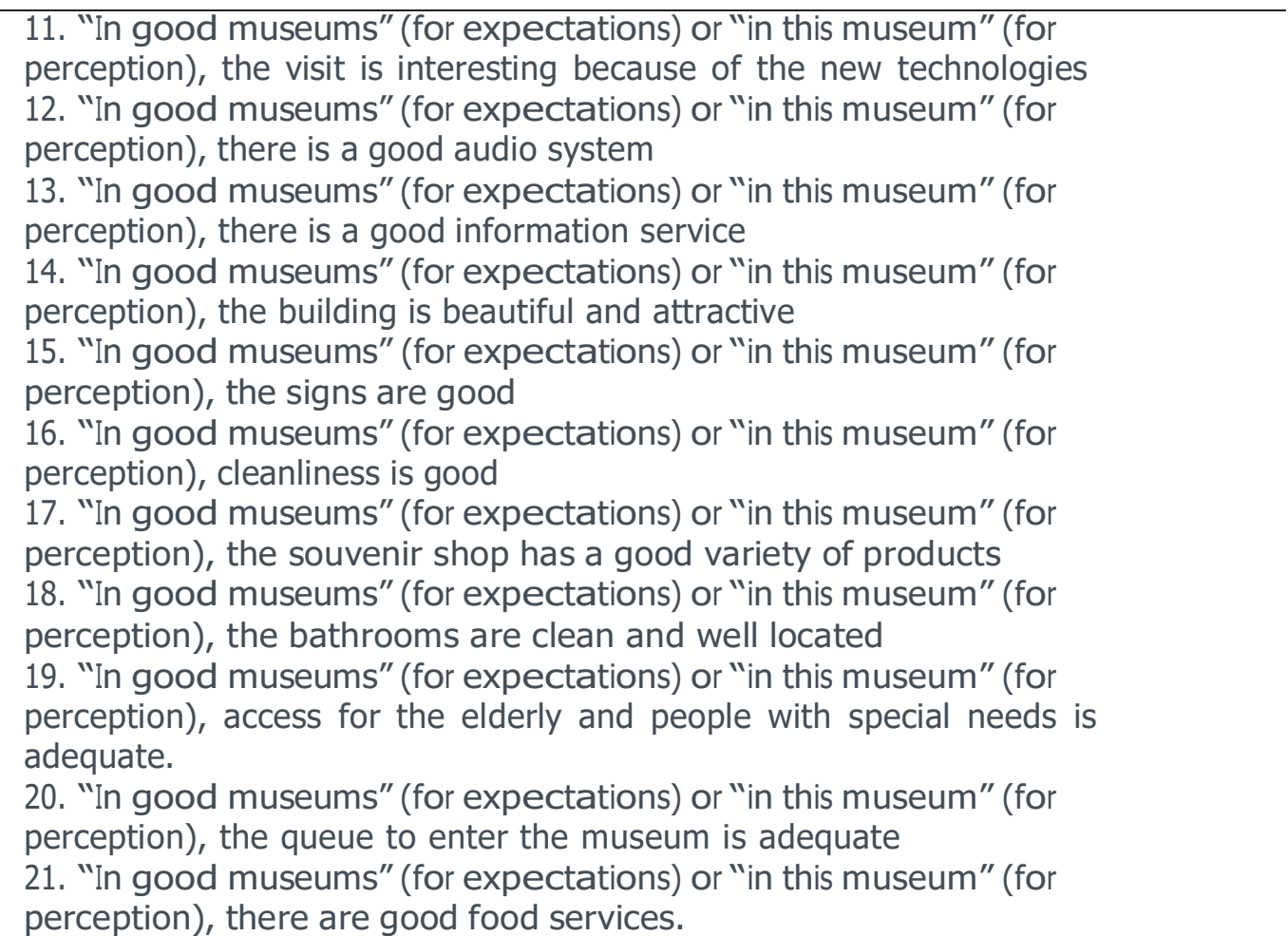

Source: Authors

The HISTOQUAL model rounds needed 3 measures: a measure of expectations, in 21 items, before the visit; a measure of pondered weights of each dimension, when the respondent distributes 100 points among the 5 dimensions, before the visit; and, at least, a measure of perception, in 21 items, after the visit. Quality level is done by weighted arithmetic mean of the difference between expectations and perception in each one of the 21 items pondered by the weights of each dimension (Frochot \& Hughes, 2000).

DATA ANALYSIS

About respondents, average age was 18,2 years. $68 \% \%$ were female, 38\% males. $75 \%$ was in the high-school, $18 \%$ have finished high-school and other 7\% was in college. Sample's average household income was R\$ 2912.

Results have shown that a higher degree of use of technology can increase arousal and WOM recommendation intentions regarding museums, as 
compared to ones with a lower degree of technology usage: Correlations were stronger for high-IT museums than for low-IT ones; and the means were higher, and Levene test rejected hypothesis for equal means $(p>0,05)$ for all the independent variables: Arousal (5,51 high; 5,24, low), E-WOM (5,78 high; 5,53, low), Quality perception (5,80 high; 5,55 low), and Quality expectation (5,9 high; 5,8 low).

In despite of the three museums with higher technological means also being higher in terms of generated arousal and WOM recommendation intentions (as compared to ones with lesser means), the highest means were based on the Federal museum visit, where the guide was very friendly. We consider that as being a result of empathy.

All three hypotheses were confirmed. H1 was only confirmed for museums with higher levels of technology. The correlation between the confirmation of quality (perception higher than expectation) and arousal was significant and positive.

Hypothesis 2 was confirmed by a t-test of means difference. All means on museums with higher IT were higher than those of museums with lower IT (test $t$ $>0,05)$. Additionally, disconfirmation of quality was almost 4 times higher on Low IT museums than on High IT ones. Hypothesis 3 was confirmed, as correlation is higher on High IT museums than on Low IT ones. In Table 4, it is possible to see all the data.

Table 5 shows data from each dimension of Histoqual. It is possible to see that high-tech museums have higher evaluation in all dimensions, and the gap between high and low-tech museums is higher on presentation dimension. Federal and Sacred Art museums have offered guides to the group, while Pinacoteca offers a personal audio guide for a fee. MAC have offered a partial guide, in just one of 5 available floors (out of a possible seven floors, two were closed). The soccer, Portuguese language, catavento, MAM, and Afro Brazil museums used to offer personal guides - but they were not 
available to students during the visit. Afro Brazil, MAM, MAC, and the Portuguese language museum made students wait in line for over 20 minutes to start their visit. Additionally, the soccer museum was paired with a temporary exhibition about the Paralympic games-along with three athletes in the fields of basketball, cycling, and athletics - there in person, with their medals.

Table 3. Museums in the study, visitation, and level of technology usage

\section{Museums (all of them located Description in São Paulo, Brazil)}

\section{Sacred art museum}

(http://www.museuartesacra.o $\mathrm{rg} \cdot \mathrm{br} /$ )

São Paulo Modern art Museum - MAM (http://mam.org.br)
This museum is a result of a partnership between public and religious organizations. Founded in 1970, its collection of sacred art started to be formed at the beginning of the 20th century; and its inventory lists more than 130,000 works from 56 countries.

MAM is a private museum founded in 1948. Its collection contains more than 5,000 works by the most representative modern and contemporary artists, principally Brazilian ones. Both the collection and exhibitions give special emphasis to the experimental works.

\section{Soccer}

(http://www.museudofutebol.o rg.br/redirect.php?struc=/\&lan $\mathrm{g}=\mathrm{en}$ )

Afro Brazil museum (http://www.museuafrobrasil.or g.br/)

Pinacoteca museum

Located in a public stadium, its total area is 7,000 square meters. It is totally dedicated to Brazilian soccer-Brazilian players, teams, and national idols.

Over 6,000 works highlight the importance of African people in the formation of Brazilian culture,

Museum heritage, and identity

Pinacoteca de São Paulo is a 81 visitors, in three

Visitation (days
and number of
students)
68 visitors, 3 visits
(in June and
December, 2016).
38 visitors, in one
visit (in September
2016 ).

14 visitors, in two visits (in and June 2016). projections, touch pads, high-quality projections, and audio recordings. There is an app which is able to be synchronized with mobile devices.

38 visitors, in one visit (in September 2016).
Low. All the interactivity provided by human monitors.

Low. All the 
(http://pinacoteca.org.br/en/h ome-en/)

Portuguese language museum (http://museudalinguaportugu esa.org.br/en/)

Contemporary art museum of University of São Paulo - MAC (www.mac.usp.br) museum of visual arts with an emphasis on Brazilian production of artwork from the nineteenth century to the present day. Founded in 1905 by the São Paulo State Government, it is the city's oldest art museum.

This is a museum where what is featured is the Portuguese language, its origins, its history, its influences, and the variations it takes within the everyday lives of members of the population.

MAC was created on 1963 when University of São Paulo received a huge donation of modern artwork. Its building has 8 floors, where it is possible to see contemporary and modern art (including paintings and sculptures).
Brazilian Federal Bank Museum (http://www.caixacultural.gov. br)

Catavento Museum of Science (http://www.cataventocultural. org.br/home_us)
It has almost 2,000 works, including paintings, sculptures, and photographic works (mainly modern art).

A museum focused on the teenage public, offering scientific, educational and interactive content (such as biology, astronomy, physics, and zoology, among others). visits (in June 2015, December, 2015, and June, 2016).

20 visitors, in two visits (in June 2015).

38 visitors, in one visit (in September 2016).

19 visitors, in one visit (in June 2016).

14 visitors, in two visits (in October 2015 and June 2016). interactivity is provided by human monitors or an electronic guide system. In one exhibition, one work was touchable.

High. There are several screens with videos. There are also 3D projections, touch pads, and digital games.

Low. All the interactivity is provided by human monitors. Some works are touchable, where it is possible to interact with it: For example, one work is a giant couch in the form of a tiger, on which one is allowed to sit and take pictures. Also, some exhibitions have videos.

Low. All the

interactivity is provided by human monitors.

High. There are several screens with videos. There are also interactive games, 3D projections, touch pads, high-quality projections, and touchable works.

Source: authors

It is possible to see that museums with higher levels of technology usage were evaluated as being better in each of the dimensions of the HISTOQUAL scale, when we compared the means of these with those of museums with lower ones. Higher differences occurred in the presentation dimension, where technology is evaluated.

Also, museums that have offered personal guides were evaluated as being better on the communication dimension. A good personal guide can increase all the grades and, probably, all the experience quality. By contrast, students gave evaluations of the worst degree to museums where they 
waited for the entrance in lines. At this point, it is important to note that MAC may have been the worst, and that, during the wait, the MAC attendees had a complaint regarding the noise of a small group of students. Maybe this fact, aligned with a partial and, probably, few empathic guidance, decreased their grades.

It is coherent with generation Z profile, based on theory (Feitosa \& Lourenço, 2018), however, results show that personal contact can be more effective than technology itself in terms of arousal generation and quality confirmation.

Table 4. Comparison of museums with high and low technology (IT)

\begin{tabular}{llll}
\hline Correlations & High IT & Low IT & Hyphotesis \\
\hline AROUSAL $\rightarrow$ E-WOM & $0,87^{*}$ & $0,81^{*}$ & H3 supported \\
\hline Q (E-P) $\rightarrow$ AROUSAL & $0,63^{*}$ & 0,10 & H1 supported on High IT \\
\hline Q (P) $\rightarrow$ AROUSAL & $0,68^{*}$ & $0,53^{*}$ & H1 supported \\
\hline Q (E) $\rightarrow$ Q (P) & 0,06 & $0,45^{*}$ & \\
\hline Means & High IT & Low IT & Hyphotesis \\
\hline WOM* & 5,76 & 5,50 & H2 supported \\
\hline Arousal* & 5,52 & 5,21 & H2 supported \\
\hline Q (P)* & 5,80 & 5,53 & H2 supported \\
\hline Q (E)* & & & \\
Q (E-P) & 5,88 & 5,76 & H2 supported \\
\hline P $<0,01$ & 0,08 & 0,23 & \\
\hline
\end{tabular}

Source: authors

Table 5. Evaluation of museums in each dimension of HISTOQUAL

$\begin{array}{lllll}\text { IT Museum Tangibility } & \begin{array}{l}\text { Ease to Empathy Presentation Comunication Total } \\ \text { access }\end{array}\end{array}$




\begin{tabular}{llllllll}
\hline High & Catavento & 5,93 & 6,24 & 6,29 & 6,26 & 5,68 & 6,08 \\
\hline & Soccer & $\mathbf{6 , 2 6}$ & $\mathbf{6 , 3 7}$ & 6,23 & $\mathbf{6 , 4 9}$ & 6,08 & 6,29 \\
\hline \multirow{2}{*}{ Low } & Portuguese & 5,32 & 5,67 & 5,65 & 5,71 & 4,45 & 5,36 \\
\hline & Total & 5,84 & 6,09 & 6,06 & 6,15 & 5,40 & 5,91 \\
\hline & 5,19 & 5,77 & 5,79 & 5,95 & 4,36 & 5,41 \\
\hline & Sacred Art & 5,54 & 5,94 & 5,73 & 5,47 & $\mathbf{6 , 4 3}$ & 5,82 \\
\hline & Federal & 6,14 & 6,32 & $\mathbf{6 , 3 9}$ & 6,14 & $\mathbf{6 , 8 2}$ & $\mathbf{6 , 3 6}$ \\
\hline MAC & 5,34 & 5,49 & 4,95 & 5,06 & 3,80 & $\mathbf{4 , 9 3}$ \\
\hline & MAM & 5,34 & 5,33 & 4,99 & 5,22 & 4,65 & 5,11 \\
\hline & Pinacoteca & 5,74 & 5,77 & 5,35 & 5,44 & 5,68 & 5,60 \\
\hline & Total & 5,55 & 5,77 & 5,53 & 5,55 & 5,29 & 5,54 \\
\hline
\end{tabular}

Source: Authors

\section{FINAL THOUGHTS}

This study allowed the research question to be answered. Considering Generation $Z$ as being an important part of visitors of any museum, today and in future, it is necessary adopt all kinds of technology to increase their experience at museums. That is a strategic issue for museums. Despite technology levels allowing a higher emotional charge and greater e-WOM recommendation intentions, operational issues are already important. Instead of just increasing spending on technology, it is better to spend money on training and internal organization-to avoid any risk of conflict.

Content is important; and interactive games, virtual reality, and audio guides can help to make content more accessible and understandable. However, courtesy and empathy are highly important in any service. Moreover, at this point, any technology can replace human beings.

Technology can improve a museum's educational goals. People will get deeper on content, and probably will share it with friends. Generation Z expects that. 
Some future research directions can receive attention for the academy. A first question that comes from the study's results is: How can word of mouth and arousal change in terms of conceptual and abstract art, as compared to representative and objective art? Considering the "selfie" culture of Generation Z, how can they interact with, and be impressed by, representative art? Other direction is about how the digital arts will interact with the traditional arts in museums. Moreover, how do quality, arousal, and word-of-mouth recommendations change when it comes to virtual museums?

\section{REFERENCES}

Becker, H. (1991) A pattern of generations and its consequences. Proceedings of Symposium of Dynamics of Cohort and Generations Research, University of Utrecht. Amsterdam Thesis Publishers.

Berger, J. (2011) Arousal increases social transmission of information. Psychological Science, 22 (7), 891-893.

Berger, J. \& Milkman, K. (2012) What makes online content viral? Journal of Marketing Research, 49 (April), 192-205. https://doi.org/10.1509/jmr.10.0353

Bonacchi, C. (2017) Museum websites \& social media. Issues of participation, sustainability, trust and diversity. International Journal of Heritage Studies, 23 (3), 291-292. https://doi.org/10.1080/13527258.2016.1232301

Botha, E. \& Reyneke, M. (2013) To share or not to share: The role of content and emotion in viral marketing, Journal of Public Affairs, 13(2), 160-171. http://dx.doi.org/10.1002/pa.1471 
Bolin, G. \& Westlund, O. (2009) Mobile generations - The role of mobile technology in the shaping of Swedish media generations. International Journal of Communication, 3, $108-124$.

Brida, J., Meleddu, M. \& Pulina, M. (2012) Factors influencing the intention to revisit a cultural attraction - The case of the Museums of Modern and Contemporary Art in Rovereto. Journal of Cultural Heritage, 13 (2), 167 - 174.

Bruyn, A. D. \& Lilien, G. L. (2008) A multi-stage model of word-of-mouth influence through viral marketing. International Journal of Research in Marketing, 25, 151-163. http://dx.doi.org/10.1016/j.ijresmar.2008.03.004

Burton, C., Louviere, J. \& Young, L. (2009) Retaining the visitor, enhancing the experience: Identifying attributes of choice in repeat museum visitation. International Journal of Nonprofit and Voluntary Sector Marketing, 14, 21-34. http://dx.doi.org/10.1002/nvsm.351

Camarero, C., Garrido, M. J. \& San José, R. (2016) Efficiency of web communication strategies: The case of art museums. International Journal of Arts Management, 18 (2), 42-62.

Carrasco-Santos, M. J. \& Padilla-Meléndez, A. (2016) The role of satisfaction in cultural activities' word-of-mouth - A case study in the Picasso Museum of Málaga (Spain). Tourism \& Management Studies, 12 (1), 145-152. http://dx.doi.org/10.18089/tms.2016.12115

Carrier, L., Cheever, N., Rosen, L., Benitez, S. \& Chang, J. (2009) Multitasking across generations: Multitasking choices and difficulty ratings in three generations of Americans. Computers in Human Behavior, 25 (2), 483-489.

Charitonos, K., Blake, C., Scanlon, E. \& Jones, A. (2012) Museum learning via social and mobile technologies: (How) can online interactions enhance the visitor experience? British Journal of Educational Technology, 43 (5), 802-819. 
Christal, M.; Roy, L.\& Cherian, A. (2004) Stories told: Tribal communities and the development of virtual museums. Journal of Internet Cataloging. 7 (1), 65-88. http://dx.doi.org/10.1300/J141v07n01_05

Christensen, H. D. (2017) The art of copying: Five strategies for transforming originals in the art museum. Culture Unbound: Journal of Current Cultural Research, 9 (1), 85-107. http://dx.doi.org/10.3384/cu.2000.1525.179185

Chung, J., Park, N., Wang, H., Fulk, J. \& Mclaughlin, M. (2010) Age differences in perceptions of online community participation among non-users: An extension of the Technology Acceptance Model. Computers in Human Behavior, 26 (6), 1674-1684.

Claes, F. \& Deltell, L. (2014) Museos sociales - Perfiles museísticos en Twitter y Facebook 2012-2013. El profesional de la información, 23 (6), 594-602. https://doi.org/10.3145/epi.2014.nov.06

Derbaix, M. \& Gombault, A. (2016) Selling the invisible to create an authentic experience: Imagination at work at Cézanne's studio. Journal of Marketing Management, 32 (15-16), 1458-1477.

Dossin, L. \& Riphagen, M. (2017) O workflow da publicação híbrida. In P. Gobira \& T. Muccelli (Eds.), Configurações do pós-digital, 266 - 276. Belo Horizonte: edUEMG. http://labfront.weebly.com/livro-pos-digital.html

Feitosa, W., \& Lourenço, C. (2018). Diferencias de envolvimiento con productos entre cohortes: un estudio exploratorio. Cuadernos Del Cimbage, 2(20), 39-54.

Fraga, T. (2017) Mindflutuations: Cenários alternativos em BCI (Brain Computer Interaction). In P. Gobira \& T. Muccelli (Eds.), Configurações do pós-digital, 100-112. Belo Horizonte: edUEMG. http://labfront.weebly.com/livro-posdigital.html 
Frey, B. (1998) Super museums: An economic analysis. Journal of Cultural Economics, $22(2-3), 113-125$.

Frochot, I. \& Hugues, H. (2000) HISTOQUAL: The development of a historic houses assessment scale. Tourism Management, 21 (2), 157 - 167. https://doi.org/10.1016/S0261-5177(99)00045-X

Geismar, H. \& Mohns, W. (2011) Social relationships and digital relationships: Rethinking the database at the Vanuatu Cultural Centre. Journal of the Royal Anthropological Institute, 17, 133-155. http://dx.doi.org/10.1111/j.14679655.2011.01693.x

Gomide, J. (2017) Tendências e aplicações da realidade aumentada. In Gobira, P. \& Muccelli, T. (Ed.) Configurações do pós-digital, 125-142. Belo Horizonte: edUEMG. http://labfront.weebly.com/livro-pos-digital.html

Gosling, M., Coelho, M. \& Resende, M. (2014) Qualidade percebida e intenções comportamentais de visitantes de museus: Uma proposta de modelo. Revista turismo: Visão e ação, 16 (3). doi: 10.14210/rtva.v16n3.p656689

Hackley, C. \& Tiwsakul, R. (2006) Entertainment Marketing and Experiential Consumption, Journal of Marketing Communications, 12 (1), 63-75.

Hausmann, A. (2012) The importance of word of mouth for museums: An analytical framework. International Journal of Arts Management, 14 (3), 32-43.

Helsper, E. \& Eynon, R. (2010) Digital natives - Where is the evidence? British Educational Research Journal, 36 (3), 2010.

Ibram: Portal do Instituto Brasileiro de Museus (2011). Museus em números. Instituto Brasileiro de Museus. Retrieved from http://www.museus.gov.br/museus-em-numeros/ 
Issa, T. \& Isaias, P. (2016) Internet factors influencing generations $Y$ and $Z$ in Australia and Portugal: A practical study. Information Processing \& Management, 52 (4), 592-617. https://doi.org/10.1016/j.ipm.2015.12.006

Jacobsen, W. C. \& Forste, R. (2011) The wired generation: Academic and social outcomes of electronic media use among university students. Cyberpsychology, Behavior, and Social Networking, 14 (5), 275-280.

Kamal, M. \& Pramanik, S. A. (2015) Identifying factors influencing visitors to visit museums in Bangladesh and setting marketing strategies for museums. IOSR Journal of Business and Management (IOSR-JBM), 17 (10), 85-92. doi: $10.9790 / 487 X-171028592$

Kim, J., Ritchie, B. \& Mccormick, B. (2012) Development of a scale to measure memorable tourism experiences. Journal of Travel Research, 51 (12). https://doi.org/10.1177\%2F0047287510385467

Kotler, N., Kotler, P. \& Kotler, W. (2008) Museum marketing and strategy: Designing missions, building audiences, generating revenue and resources. San Francisco, CA: Jossey-Bass.

Larkin, B. \& Fink, J. (2016) Fantasy Sport, FoMO, and Traditional Fandom: How Second-Screen Use of Social Media Allows Fans to Accommodate Multiple Identities. Journal of Sport Management, 30 (6), $643-655$.

Lazzeretti, L. \& Capone, F. (2015) Museums as societal engines for urban renewal[:] The event strategy of the Museum of Natural History in Florence. European Planning Studies, 23 (8), 1548-1567.

Lovelock, C. \& Wirtz, J. (2011) Services marketing: People, technology, strategy (7th ed.). Pearson: Prentice Hall.

Mastrodicasa, J. \& Metellus, P. (2013) The impact of social media on college students. Journal of College \& Character, 14 (1). 
Mccarthy, J. \& Ciolfi, L. (2008) Place as dialogue: Understanding and supporting the museum experience. International Journal of Heritage Studies, 14 (3), 247-267. https://doi.org/10.1080/13527250801953736

Ooi, C. S. (2003) Identities, museums and tourism in Singapore: Think regionally, act locally. Indonesia \& the Malay World. 31 (89), 80. https://doi.org/10.1080/13639810304445

Parasuraman, A., Zeithaml, V. \& Berry, L. (1988) SERVQUAL: A multiple-item scale for measuring consumer perceptions of service quality. Journal of retailing, $64(1)$.

Plaza, B. (2000) Evaluating the Influence of a Large Cultural Artifact in the Attraction of Tourism - The Guggenheim Museum Bilbao Case. Urban Affairs Review, 36 (2).

Pierroux, P.; Krange, I. \& Sem, I. (2011) Bridging contexts and interpretations: Mobile blogging on art museum field trips. MedieKultur - Journal of media and communication research, 50, 30 - 47. http://dx.doi.org/10.7146/mediekultur.v27i50.2997

Priporas, C.V., Stylos, N. \& Fotiadis, A. K. (2017) Generation Z consumers' expectations of interactions in smart retailing: A future agenda. Computers in Human Behavior, 77, 374 -381. https://doi.org/10.1016/j.chb.2017.01.058

Richani, E. (2016) Strategic marketing in museum management - An indicative marketing plan for the Byzantine and Christian Museum based on secondary analysis. Dissertation. Ionian University.

Runcan, R. (2015) Facebookmania - The psychical addiction to Facebook and its incidence on the Z Generation. Revista de Asistenta Social [Social Work Review], 14 (3), 127 - 136.

Russo, A., Watkins, J., Kelly, L. \& Chan, S. (2007) Social media and cultural interactive experiences in museums. Nordisk Museologi, 1, 19-29. 
Russo, A., Watkins, J. \& Groundwater-Smith, S. (2009) The impact of social media on informal learning in museums. Educational Media International., 46 (2), 153-166. https://dx.doi.org/10.1080/09523980902933532

Ryder, N. B. (1965) The cohort as a concept in the study of social change. American Sociological Review, $30 \quad$ (6), $843 \quad$ - 861. http://dx.doi.org/10.2307/2090964

Samodra, A. \& Mariani, M. (2012) Determinants of intention to use social networking media among Generation Z in Indonesia. Proceedings of Annual International Conference on Computer Science Education: Innovation \& Technology. doi:10.5176/2251-2195_CSEIT12.28

Smith, J. \& Clurman, A. (1997) Rocking the ages. New York: HarperBusiness.

Srinavasan, R.; Boast, R.; Becvar, K. M. \& Furner, J. (2009) Blobgects: Digital museum catalogs and diverse user communities. Journal of the American Society for Information Science \& Technology, 60 (4), 666-678. http://doi.org/10.1002/asi.21027

Strauss, W.\& Howe, N. (1991) Generations. New York: Quill William Morrow.

Suzić, B.; Karlíček, M. \& Stř́teský, V. (2016) Adoption of social media for public relations and museums. Central European Business Review, 5 (2), 5 - 16. https://doi.org/10.18267/j.cebr.148

Swiss, T. \& Hanna, J. (2004) New media poetry, institutional support, and art museums. New Media \& Society, 6 (1), 82-86, 2004.

https://doi.org/10.1177/1461444804039916

Tallon, L. \& Walker, K. (2008). Digital technologies and the museum experience: Handheld guides and other media. Lanham, US: AltaMira Press. ISBN: 978-0759111219. 
Turner, A. (2015) Generation Z: Technology and social interest. Journal of Individual Psychology, 71 (2), 103-113, 2015.

Vavoula, G.; Sharples, M.; Rudman, P.; Meek, J. \& Lonsdale, P. (2009) Myartspace: Design and evaluation of support for learning with multimedia phones between classrooms and museums. Computers \& Education, 53, 286 299. https://doi.org/10.1016/j.compedu.2009.02.007

Vrana, V., Kydros, D., Kehris, E., Theocharidis, G. \& Kavavaridis, E. (2019) Top Museums on Instagram: A Network Analysis. International Journal of Computational Methods in Heritage Science, 3 (2).

Waiguny, M., Nelson, M. \& Terlutter, R. (2012) Entertainment matters! The relationship between challenge and persuasiveness of an advergame for children, Journal of Marketing Communications, 18 (1), 69-89 